International Journal of Surgical Pathology 12(2):117-125, 2004

\title{
Neuroendocrine Cells in Barrett's Mucosa and Adenocarcinomas of the Gastroesophageal Junction
}

\author{
Linetta B. Koppert, MD, *† Bas P. L. Wijnhoven, MD, PhD,* \\ Hugo W. Tilanus, MD, PhD, * Theo Stijnen, PhD, $\neq$ \\ Herman van Dekken, MD, PhD, ${ }^{\dagger}$ and Winand N. M. Dinjens, PhD ${ }^{\dagger}$
}

\begin{abstract}
We estimated the prevalence and prognostic significance of neuroendocrine (NE) cells in a series of 208 resection specimens containing gastroesophageal junction (GEJ) adenocarcinomas, with 56 specimens containing Barrett's mucosa. Immunohistochemically, chromogranin A (CGA) was positive in 49\% (102/208) of GEJ adenocarcinomas and in $68 \%(38 / 56)$ of Barrett's mucosas. CGA in GEJ tumors correlated with pTNM stage. CGA in Barrett correlated with pTNM stage and tumor grade of the adjacent carcinoma. Patients with CGA in Barrett had better survival than patients without CGA in Barrett, with 5-year survival percentages of $56 \%$ and $9 \%$, respectively. In multivariate analysis, CGA in Barrett was an independent prognostic factor for survival after surgery. Therefore CGA in Barrett adjacent to GEJ adenocarcinoma might be helpful in the assessment of patient outcome. Int J Surg Pathol 12(2):117-125, 2004

Key words: Barrett's mucosa, adenocarcinomas of the gastroesophageal junction, neuroendocrine cells, chromogranin A, immunohistochemistry.
\end{abstract}

Neuroendocrine (NE) cells are defined as argentaffin and argyrophil cells that produce peptides or amines. They belong to the diffuse neuroendocrine system (DNES) and were previously known as amino-precursor-uptake-decarboxylation (APUD) cells. The neuroendocrine system of the normal gastrointestinal tract might regulate proliferation and growth of epithelial and mesenchymal cells and probably function in sensation of hunger during fasting and food-intake [1]. Chromogranin

From the Departments of *Surgery, +Pathology, Josephine Nefkens Institute, and ‡Epidemiology and Biostatistics, Erasmus MC, University Medical Center Rotterdam, The Netherlands (on behalf of the Rotterdam Esophageal Tumor Study Group).

LBK is sponsored by the Dutch Cancer Society/KWF.

Reprint requests: W. N. M. Dinjens, Department of Pathology, Josephine Nefkens Institute, Erasmus MC, University Medical Center Rotterdam, P.O. Box 1738, 3000 DR, Rotterdam, The Netherlands.
A (CGA), a specific matrix component of endocrine granules, participates in vesicle aggregation, granulogenesis, and hormone secretion and serves as a precursor for bioactive peptides (prohormone function) in endocrine and NE cells [2-4]. CGA is stored in secretory granules of NE cells and is regarded as a general endocrine marker [5-7]. The presence of NE cells in carcinomas of the gastrointestinal tract is well documented but their role remains speculative [8-21]. In a number of immunohistochemical studies a prognostic relevance of NE cells in adenocarcinomas, mostly colorectal adenocarcinomas, has been reported, however, several other studies failed to demonstrate a relation between NE differentiation and biological behavior of colorectal adenocarcinomas [9-11,14-22]. Reports on the prevalence and prognostic significance of NE cells in adenocarcinomas of the esophagus and its precursor lesion, the Barrett's mucosa, have been scarce. Hamilton et al. [23] did not find a significant correlation be- 
tween the presence of chromogranin A (CGA) immunoreactive tumor cells and survival in patients with esophageal adenocarcinoma. We analyzed the presence of NE cells in 208 resection specimens with adenocarcinoma of the gastroesophageal junction (GEJ), i.e., gastric cardia or distal esophagus, and premalignant Barrett's mucosa and correlated immunostaining with tumor characteristics and patient survival in order to evaluate the possible application of NE cells as prognostic marker.

\section{Materials and Methods}

\section{Tissues and Patients}

Two hundred and eight patients (176 men; 32 women) with GEJ adenocarcinoma who underwent transhiatal resection of the tumor with restoration of continuity of the gastrointestinal tract by a gastric tube with cervical anastomosis were included in this study. Patients were operated on between April 1987 and April 2002 at the Department of Surgery, Erasmus MC, Rotterdam. A standard dissection of the perigastric, left gastric, and celiac nodes was performed. Macroscopic tumor clearance was aimed at in all cases but no extended lymph node dissection was done. Seventeen patients received neoadjuvant chemotherapy and 2 patients received neoadjuvant chemoradiation. Patients' mean age was 63.6 years (range $39-84$ years) at the time of diagnosis. All patients were followed up until April 2003 or until death if earlier. All 208 pathology records were reviewed. Barrett's mucosa was diagnosed by the GI-pathologist and was defined as the presence of intestinal-type epithelium with Goblet cells in the tubular esophagus [24].

In 73 patients Barrett's mucosa had been sampled before development of adenocarcinoma. Barrett's mucosa adjacent to tumor could be obtained in 56 of these 73 resection specimens, whereas in 17 resection specimens the Barrett's mucosa could not be detected. Barrett's mucosa showed no signs of dysplasia in 22, low-grade dysplasia in 22, and highgrade dysplasia in 12 resection specimens. A carcinoma was considered to arise from the distal esophagus when premalignant Barrett's mucosa was present and/or the epicenter of the mass was located in the tubular esophagus extending from the tracheal bifurcation to the gastroesophageal junction including the intraabdominal esophagus, according to the TNM classification (International Classification of Diseases for Oncology C15.5). The tumor was considered to be cardiac when the epicenter was immediately below the gastroesophageal junction, extending approximately $2 \mathrm{~cm}$ down- ward. The tumor was classified as a junction carcinoma when the epicenter was just at the GEJ, without predominance for distal esophagus or gastric cardia and no Barrett's mucosa was present. Tumors arising from the fundus or corpus of the stomach and infiltrating the gastric cardia or distal esophagus were excluded. Of the adenocarcinomas in our patient group, 112 arose from the distal esophagus and 73 arose from the cardia. The exact location of 23 GEJ adenocarcinomas could not be specified as either distal esophagus or gastric cardia and these were classified as junction carcinomas.

\section{Immunohistochemical Analyses}

From formalin-fixed, paraffin-embedded tissue blocks of the primary tumor, 4 - $\mu$ m-thick sections were mounted on 3-aminopropyl-triethoxysilane (APES)-coated glass slides. For immunostaining a monoclonal antibody against CGA (Hybritech, San Diego, USA, at a dilution of $1: 1,250$ ) was used. Staining was carried out by a standard avidin biotin immunoperoxidase technique, using a commercially available kit (Labvision, Fremont, USA). Deparaffinized sections were treated with methanol containing $3 \% \mathrm{H}_{2} \mathrm{O}_{2}$ for 20 minutes. After washing with phosphate-buffered saline (PBS), blocking serum was applied for 5 minutes. Then, primary CGA antibodies were allowed to react at room temperature for 1 hour. After washing in PBS, biotin-conjugated secondary antibody was applied for 10 minutes followed by peroxidase-marked streptavidin. After rinsing in PBS, peroxidase was visualized by diaminobenzidine hydrochloride (Fluka, Neu-Ulm, Germany) with $0.03 \% \mathrm{H}_{2} \mathrm{O}_{2}$ solution for 10 minutes. The slides were counterstained with Mayer's Hematoxylin and dehydrated in alcohol before mounting. Expression of CGA was evaluated by high-power microscopic examination $(400 \times)$ of the entire tissue section. As negative controls normal mouse immunoglobulins and normal rabbit serum were applied on duplicate sections. Positive controls using normal colonic epithelium were also run with each batch, in addition to using noninvolved normal gastric mucosa in the resection specimens, if present, as an internal positive control. Scoring of cytoplasmic CGA expression in adenocarcinomas was based on the percentage of positive cells: $>20 \%$ of cells with cytoplasmic staining $(2+), 1-20 \%$ of cells with cytoplasmic staining $(1+)$, no cells staining $(0)$.

\section{Statistical Analysis}

Correlations between CGA immunoreactivity and patient and tumor characteristics were assessed by $t$ test and (a trend version of ) $\chi^{2}$ test. Survival 
rates were calculated according to the Kaplan-Meier method and differences in survival were assessed by using the log rank test; $\mathrm{p}<0.05$ was considered statistically significant. The Cox regression model was used to analyze the independent prognostic value of CGA expression after correction for possible confounding factors.

\section{Results}

CGA expression was detected in 102/208 (49\%) adenocarcinomas of the GEJ (Table 1). The CGApositive cells mostly presented diffusely scattered throughout the tissue or multifocally located in small nests, with just 8 tumors having $>20 \%(2+)$ CGA-positive cells (Fig. 1). For statistical comparison we hence combined the groups with $1+$ and $2+$ staining. Negative controls did not show staining, and positive controls were positive. In 56 of the 208 resection specimens Barrett's mucosa adjacent to adenocarcinoma was detected. Positive staining for CGA was seen in 38/56 cases $(68 \%)$. CGA immunoreactivity was absent in $18 / 38(47 \%)$ tumors with CGA-positive Barrett's mucosa (Table 1). There was no correlation between CGA immunoreactivity in Barrett's mucosas and CGA immunoreactivity in adenocarcinomas $(p=0.57)$. In the patients with Barrett's mucosa adjacent to tumor, there was no correlation between CGA immunoreactivity in the Barrett and presence or degree of dysplasia $(p=0.97$ and $p=0.65$, respectively).

CGA-positive staining in GEJ tumors correlated with a more favorable pTNM stage $(p=0.04$, Table 2). CGA-positive staining in Barrett's mucosas correlated with a more favorable pTNM stage and tumor grade $(p=0.005$ and $p=0.024$, respectively, Table 2). No difference in survival between patients with CGA-positive and CGA-negative adenocarcinomas was found ( $p=0.69$, Fig. 2$)$. Five-year survival percentages were $30 \%$ and $28 \%$, respectively. However, patients with CGA-positive cells in Bar- rett's mucosa adjacent to the tumor had a better survival than patients without CGA-positive cells in Barrett's mucosa ( $p=0.0015$, Fig. 3). Five-year survival percentages were $56 \%$ and $9 \%$ for patients with and without CGA expression in Barrett, respectively. Univariate analysis to identify prognostic variables in the total group showed pTNM stage, tumor grade, and radicality of resection to be prognostic factors for survival $(\mathrm{p}=<0.001, \mathrm{p}=0.012$, and $\mathrm{p}=<0.001$, respectively). In multivariate Cox regression analysis only pTNM-stage and radicality of resection turned out to be independent prognostic factors for survival in the total patient group $(\mathrm{p}=0.003$ and $\mathrm{p}=0.006$, Table 3A). However, in the group of patients with Barrett's mucosa, univariate analysis showed age, radicality of resection, and CGA immunoreactivity in the Barrett's mucosa to be prognostic for survival $(p=0.035, p=0.008$, and $\mathrm{p}=0.003$, respectively, Table $3 \mathrm{~B})$, which was substantiated by multivariate analysis $(p=0.03$, $\mathrm{p}=0.037$, and $\mathrm{p}=0.003$, respectively, Table $3 \mathrm{~B}$ ).

\section{Discussion}

Our study, which showed that the presence of NE cells in GEJ tumors did not correlate with 5-year survival rate, is in concordance with the results reported by Hamilton et al. [23]. They investigated the expression of CGA in 52 patients with adenocarcinomas of the esophagus and did not find a correlation with survival [23]. We also confirm their findings of CGA-positive Barrett's mucosas with adjacent CGA-negative tumors (namely, in 38\% of their tumors and in $47 \%$ of our tumors). Obviously neuroendocrine differentiation commonly disappears in invasive adenocarcinomas. We likewise observed NE cells more often in Barrett's mucosa without dysplasia or with low-grade dysplasia than in high-grade dysplastic Barrett's mucosas, although this difference lacked statistical significance. Hamilton et al. found expression of CGA in $62 \%(21 / 34)$

Table 1. CGA Expression in Adenocarcinomas of the GEJ and Barrett's Mucosa

\begin{tabular}{lcccc}
\hline & Non-Barrett & CGA Positive & CGA Negative & Total \\
\hline Adenocarcinomas & & & & \\
CGA positive & 74 & 20 & 10 & 102 \\
CGA negative & 78 & 18 & 18 & 106 \\
Total & 152 & 38 & & 208 \\
\hline
\end{tabular}



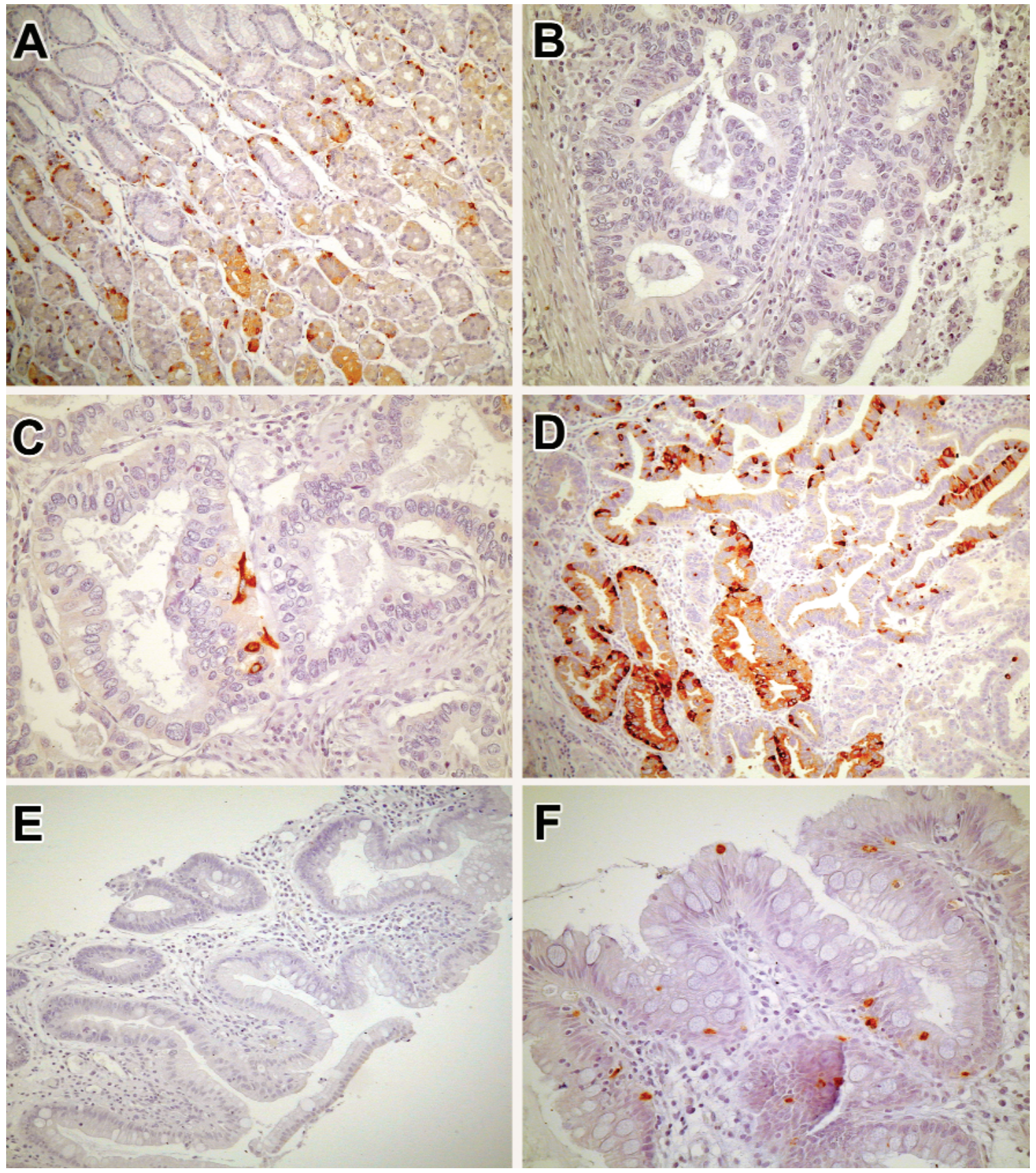

Fig. 1. A. CGA immunoreactivity in normal gastric epithelium. B. CGA-negative adenocarcinoma. C. Scatters of individual tumor cells show CGA staining $(1+)$ within a well-differentiated adenocarcinoma. D. Adenocarcinoma shows apparent cytoplasmic CGA staining in $>20 \%(2+)$ of tumor cells. E. CGA-negative Barrett's epithelium adjacent to adenocarcinoma. F. CGA-positive cells in Barrett's epithelium most prominently located in the basal layer of the epithelium.

of the Barrett's mucosas, as compared to our finding of $68 \%(38 / 56)$. In our study, patients with CGApositive Barrett's mucosa had a better survival rate than patients with CGA-negative Barrett's mucosa. Our study differs from the study of Hamilton et al. in several ways. The monoclonal CGA antibody we used differs from the antibody used by Hamilton et al. Our study encompasses 208 patients versus 52 patients in the study of Hamilton et al. Finally, their population contained 37 of 52 patients who underwent preoperative therapy, compared to 19 of our 208 patients, and this might influence CGA stain- 
Table 2. Clinicopathological Characteristics of 208 Patients with GEJ Adenocarcinomas and Barrett's Mucosa Adjacent to Tumor (If Present, 56 of 208 Patients)

\begin{tabular}{|c|c|c|c|c|c|c|c|c|}
\hline \multirow[b]{2}{*}{ Variable } & \multicolumn{4}{|c|}{ Chromogranin A in Tumor } & \multicolumn{4}{|c|}{ Chromogranin A in Barrett's Mucosa } \\
\hline & $\begin{array}{l}\text { Number of } \\
\text { Tumors } \\
\text { Positive } \\
(\%)\end{array}$ & $\begin{array}{c}\text { Number of } \\
\text { Tumors } \\
\text { Negative } \\
(\%)\end{array}$ & $\begin{array}{c}\text { Total } \\
\text { Number of } \\
\text { Tumors } \\
(\%)\end{array}$ & $\mathrm{p}$ Value* & $\begin{array}{c}\text { Number of } \\
\text { Barrett's } \\
\text { Positive } \\
(\%)\end{array}$ & $\begin{array}{c}\text { Number of } \\
\text { Barrett's } \\
\text { Negative } \\
(\%)\end{array}$ & $\begin{array}{l}\text { Total } \\
\text { Number of } \\
\text { Barrett's } \\
(\%)\end{array}$ & p Value* \\
\hline \multicolumn{9}{|l|}{ Gender } \\
\hline Male & $85(83)$ & $91(86)$ & $176(85)$ & & $30(79)$ & $17(94)$ & $47(84)$ & \\
\hline Female & $17(17)$ & $15(14)$ & $32(15)$ & 0.76 & $8(21)$ & $1(6)$ & $9(16)$ & 0.25 \\
\hline Mean age, years \pm SD & $63.6 \pm 10.1$ & $63.6 \pm 9.2$ & $63.6 \pm 9.7$ & $0.94 \dagger$ & $64.8 \pm 10.0$ & $64.2 \pm 10.9$ & $64.6 \pm 10.2$ & $0.99+$ \\
\hline \multicolumn{9}{|l|}{ pTNM-stage } \\
\hline I & $11(11)$ & $5(5)$ & $16(8)$ & & $10(26)$ & - & $10(18)$ & \\
\hline II & $34(33)$ & $33(31)$ & $67(32)$ & & $16(42)$ & $4(22)$ & $20(36)$ & \\
\hline III & $48(47)$ & $50(47)$ & $98(47)$ & & $7(18)$ & $11(61)$ & $18(32)$ & \\
\hline IV & $9(9)$ & $18(17)$ & $27(13)$ & 0.04 & $5(13)$ & $3(17)$ & $8(14)$ & 0.005 \\
\hline \multicolumn{9}{|l|}{ Tumor grade } \\
\hline Well & $5(5)$ & $4(4)$ & $9(4)$ & & $4(11)$ & - & $4(7)$ & \\
\hline Moderate & $47(46)$ & $41(39)$ & $88(42)$ & & $18(47)$ & $5(28)$ & $23(41)$ & \\
\hline Poor & $50(49)$ & $61(58)$ & $111(53)$ & 0.23 & $16(42)$ & $13(72)$ & $29(52)$ & 0.024 \\
\hline \multicolumn{9}{|l|}{ Radicality } \\
\hline R0 & $71(70)$ & $76(72)$ & $147(71)$ & & $29(76)$ & $11(61)$ & $40(71)$ & \\
\hline $\mathrm{R} 1, \mathrm{R} 2$ & $31(30)$ & $30(28)$ & $61(29)$ & 0.86 & $9(24)$ & $7(39)$ & $16(29)$ & 0.39 \\
\hline \multicolumn{9}{|l|}{ Tumor location } \\
\hline Esophagus & $58(57)$ & $54(51)$ & $112(54)$ & & 38 & 18 & 56 & \\
\hline GEJ & $8(8)$ & $15(14)$ & $23(11)$ & & - & - & - & \\
\hline Cardia & $36(35)$ & $37(35)$ & $73(35)$ & 0.67 & - & - & - & - \\
\hline \multicolumn{9}{|l|}{ Dysplasia } \\
\hline Absent & & & & & $15(40)$ & $7(39)$ & $22(39)$ & \\
\hline Low grade & & & & & $16(42)$ & $6(33)$ & $22(39)$ & \\
\hline High grade & & & & & $7(18)$ & $5(28)$ & $12(21)$ & 0.65 \\
\hline
\end{tabular}

*P value by (a trend version of) $\chi^{2}$ test; $+\mathrm{P}$ value by $\mathrm{t}$ test.

ing. However, when the 19 patients who received preoperative therapy were left out from the analyses, our results did not change. Moreover, Shia et al. [25] suggested that the increased endocrine differentiation shown in rectal adenocarcinomas treated by chemo(radio)therapy could be related to therapy-induced cytotoxity, which is in contrast to the lower percentage of CGA-positive patients, although there was a higher percentage of pretreated patients in the study of Hamilton et al. as compared to our study. Since adenocarcinomas of the distal esophagus and the gastric cardia are regarded as one clinical entity by some authors [26,27], we investigated the expression of NE markers in adenocarcinomas of the GEJ, whereas in the study of Hamilton et al., only esophageal adenocarcinomas were included. Because the prevalence of NE differentiation in our series was about the same in esophageal and cardia adenocarcinomas, the different results cannot be ascribed to the fact that in our study cardia adenocarcinomas were included.

Several studies concerning colorectal carcinomas showed that the presence of CGA-positive cells does not influence prognosis [14-19], whereas other studies indicate that CGA expression in tumor cells might distinguish a subgroup of colorectal carcinomas with poorer prognosis [10-12,21]. Swatek and Chibowski [13], using immunostaining for CGA, reported that endocrine cells were significantly more frequent in less advanced and better differentiated colorectal carcinomas. Two other studies showed a significantly better survival in patients with NE expression in pancreatic cancer and nonsmall cell lung cancer $[28,29]$.

In the current study we demonstrated that CGA expression in Barrett's mucosa adjacent to the tumor 


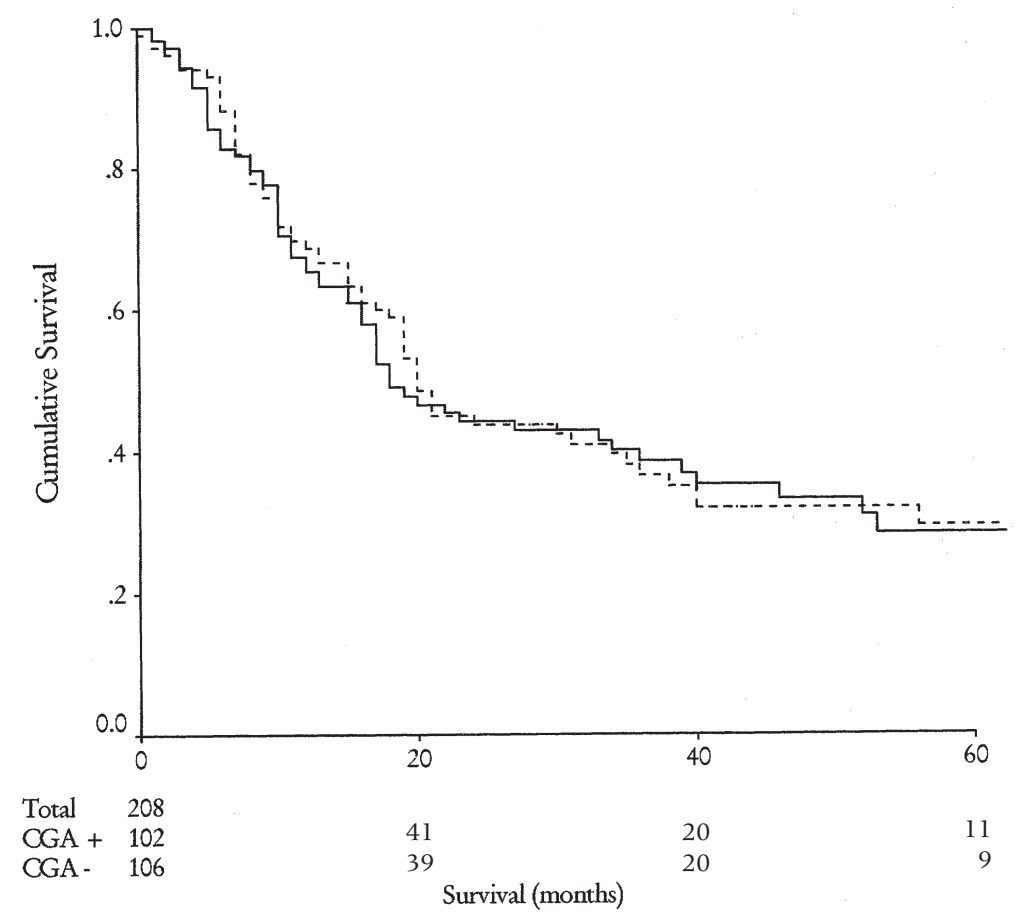

Fig. 2. Cumulative survival of patients with $(n=102)$ and without $(n=106)$ CGA immunoreactivity in adenocarcinomas of the GEJ $(p=0.69)$. Broken line represents CGApositive tumors, uninterrupted line represents CGA-negative tumors.

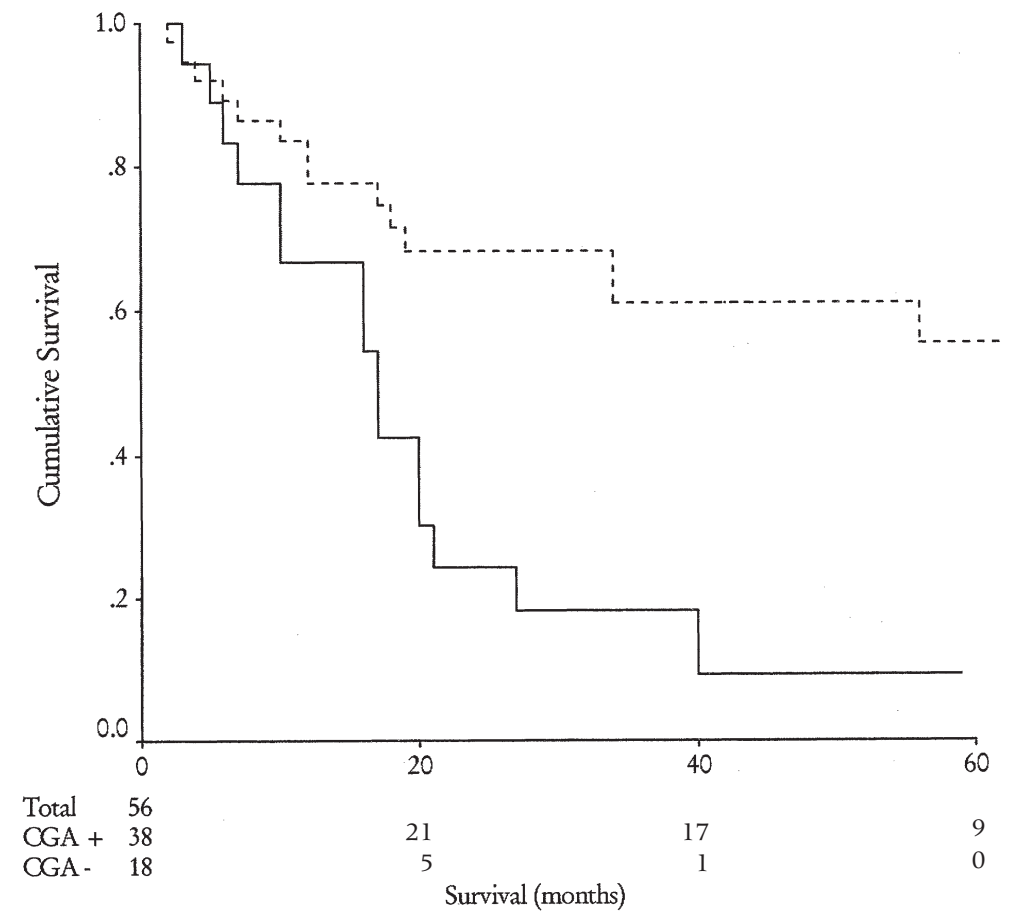

Fig. 3. Cumulative survival of patients with $(n=38)$ and without $(n=18)$ CGA immunoreactivity in Barrett's mucosa adjacent to adenocarcinoma $(p=0.0015)$. Broken line represents CGApositive Barrett's mucosas, uninterrupted line represents CGA-negative Barrett's mucosas. 
Table 3. Results of the Cox Regression Analyses in (A) 208 GEJ Adenocarcinomas and in (B) 56 Barrett's Mucosas (Adjacent to Tumor), as Part of the Series of 208 GEJ Adenocarcinomas

\begin{tabular}{|c|c|c|c|c|}
\hline \multicolumn{5}{|l|}{ A. } \\
\hline Confounding Variable & Univariate $\mathrm{RR}^{*}(\mathrm{CI}+)$ & $\mathrm{p}$ Value & Multivariate-Adjusted RR $\neq(\mathrm{CI})$ & $\mathrm{p}$ Value \\
\hline Age & $1.01(1.0-1.03)$ & 0.15 & $1.02(1.0-1.04)$ & 0.11 \\
\hline Gender $(\mathrm{M}, \mathrm{F})$ & $0.94(0.59-1.52)$ & 0.81 & $0.75(0.45-1.25)$ & 0.27 \\
\hline pTNM—stage: I & - & $<0.001$ & - & 0.003 \\
\hline II & $3.76(1.16-12.22)$ & - & $2.88(0.88-9.48)$ & - \\
\hline 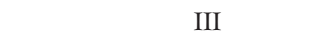 & $8.43(2.63-27.04)$ & - & $5.35(1.63-17.56)$ & - \\
\hline 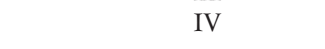 & $8.08(2.38-27.40)$ & - & $5.22(1.50-18.20)$ & - \\
\hline Tumor grade: Well & - & 0.012 & - & 0.118 \\
\hline Moderate & $6.84(0.94-49.51)$ & - & $4.95(0.68-36.04)$ & - \\
\hline Poor & $9.98(1.38-71.98)$ & - & $6.24(0.85-45.68)$ & - \\
\hline $\begin{array}{l}\text { Radicality of resection } \\
\text { (R0 vs R1, R2) }\end{array}$ & $2.43(1.69-3.49)$ & $<0.001$ & $1.73(1.17-2.57)$ & 0.006 \\
\hline $\begin{array}{l}\text { CGA tumor } \\
\text { (positive vs negative) }\end{array}$ & $1.09(0.77-1.55)$ & 0.63 & $1.12(0.78-1.61)$ & 0.56 \\
\hline \multicolumn{5}{|l|}{ B. } \\
\hline Age & $1.04(1.0-1.08)$ & 0.035 & $1.04(1.0-1.10)$ & 0.030 \\
\hline $\begin{array}{l}\text { pTNM-stage } \\
\text { (I, II vs III, IV) }\end{array}$ & $1.92(0.91-4.03)$ & 0.086 & $0.63(0.22-1.83)$ & 0.395 \\
\hline $\begin{array}{l}\text { Tumor grade } \\
\text { (well, moderate vs poor) }\end{array}$ & $1.33(0.65-2.71)$ & 0.435 & $0.93(0.35-2.45)$ & 0.883 \\
\hline $\begin{array}{l}\text { Radicality of resection } \\
\text { (R0 vs R1, R2) }\end{array}$ & $2.63(1.28-5.40)$ & 0.008 & $2.91(1.07-7.95)$ & 0.037 \\
\hline $\begin{array}{l}\text { CGA Barrett mucosa } \\
\text { (positive vs negative) }\end{array}$ & $3.12(1.48-6.58)$ & 0.003 & $4.21(1.61-11.0)$ & 0.003 \\
\hline
\end{tabular}

*Relative Risk; $+95 \%$ Confidence Interval. $\neq$ In multivariate analysis, correction was carried out for the confounding variables age, gender, pTNM stage, tumor grade, radicality of resection, and CGA immunoreactivity in the tumors (A), age, pTNM stage, tumor grade, radicality of resection, and CGA immunoreactivity in Barrett's mucosa (B), variables are mentioned in the column "Confounding Variables".

is an independent predictor of improved survival after surgery for GEJ adenocarcinomas. To our knowledge this is the first example that in the concurrent presence of a premalignant lesion and a carcinoma a characteristic of the premalignant lesion has prognostic significance. An explanation for this finding remains obscure.

The presence of NE cells in Barrett's epithelium has been described by several authors [30-34], suggesting that it arises from a multipotent gastrointestinal stem cell probably responsible for the risk of adenocarcinoma [31,34]. Smith and Haggitt [14] have provided 4 explanations for the presence of NE cells in noncarcinoid adenocarcinomas of the gastrointestinal tract: (1) entrapment of normal NE cells within the malignant tumor; (2) benign proliferation of NE cells within a malignant population of intestinal cells; (3) malignant transformation of 2 distinct stem cell lines ( 1 neuroendocrine and 1 endodermal); and (4) malignant transformation of 1 stem cell line capable of both endodermal and neuroendocrine differentiation. The last hypothesis has found support from several studies [20,35], including that by De Bruïne et al. [36], who demonstrated mucin and CGA expression in the colorectal cell line H716.

Since NE cells comprise an integral part of the intestinal epithelium, the presence of NE cells in Barrett's mucosa can be the mere result of the intestinal-type differentiation. However, additional factors in NE differentiation can be involved. Duodenogastroesophageal reflux is known to be a risk factor for the development of Barrett's mucosa. Reflux disease is often treated by acid-suppressive therapy. Sanduleanu et al. [37] found that serum CGA increases during profound gastric acid inhibition. Fur- 
thermore, Helicobacter pylori infection was associated with higher serum CGA levels [37]. It should therefore be addressed that both long-term acid-suppressive therapy and Helicobacter pylori status might play a role in CGA expression in Barrett's mucosa and adenocarcinomas of the GEJ. Unfortunately, we were not able to obtain reliable information on previous acid-suppressive therapy or Helicobacter pylori status in our patient population.

Colombo et al. [38] investigated the effect of CGA on neoplastic growth and morphogenesis by use of mouse models. They found slower progression of mouse mammary adenocarcinoma after transfection of CGA cDNA and suggested that CGA may contribute to regulate tumor growth in a negative manner. Given the fact that distal esophageal adenocarcinomas often develop from a precursor lesion, i.e., Barrett's mucosa, being present for years already before tumor formation, we were able to investigate the significance of CGA on tumor growth in 56 patients with Barrett available adjacent to tumor [39]. CGA expression in these Barrett's mucosas indeed correlated with less advanced pTNM stage and tumor grade of adjacent tumors as compared to Barrett-related carcinomas without CGA in the precursor lesion. Furthermore, CGA expression in the Barrett's mucosa came forward as an independent predictor of survival in Cox regression analysis. Future experiments focusing on transfection of CGA cDNA in Barrett's metaplasia cell lines could possibly gain more insight in the role of CGA in GEJ adenocarcinoma development.

In summary, the current study demonstrates NE differentiation in Barrett's epithelium to be correlated with survival in patients with Barrett's-associated adenocarcinomas of the GEJ. CGA immunoreactivity in Barrett's mucosa adjacent to tumor is an independent prognostic factor for better survival after surgery. It appears from these data, obtained in a large patient group, that CGA expression in Barrett's mucosa might be helpful in the prognostic assessment of patient outcome.

\section{Acknowledgments}

The authors would like to thank E. C. W. den Adel and J. van Velzen for technical assistance, C. M. Vollebregt-Uiterwijk for assistance in collecting the data, and F. van der Panne for photographic work.

\section{References}

1. Hill P, Garbaczewski L, Koppeschaar H, Thijssen JH, de Waard F, Wynder EL. Peptide and steroid hor- mones in subjects at different risk for diet-related diseases. Am J Clin Nutr 48:782-786, 1988

2. Iacangelo AL, Eiden LE. Chromogranin A. Current status as a precursor for bloactive peptides and a granulogenic/sorting factor in the regulated secretory pathway. Regul Pept 58:65-88, 1995

3. Winkler H, Fischer-Colbrie R. The chromogranins A and B: The first 25 years and future perspectives. Neuroscience 49:497-528, 1992

4. Kim T, Tao-Cheng JH, Eiden LE, Loh YP. Chromogranin A, an "on/off " switch controlling dense-core secretory granule biogenesis. Cell 106:499-509, 2001

5. Lloyd RV, Wilson BS. Specific endocrine tissue marker defied by a monoclonal antibody. Science 222:628-630, 1983

6. Chejfec G, Falkmer S, Askensten U, Grimelius L, Gould VE. Neuroendocrine tumors of the gastrointestinal tract. Pathol Res Pract 183:143-154, 1988

7. Wilson BS, Lloyd RV. Detection of chromogranin in neuroendocrine cells with a monoclonal antibody. Am J Pathol 115:458-468, 1984

8. Ulich TR, Cheng L, Glover H, Yang K, Lewin KJ. A colonic adenocarcinoma with argentaffin cells. An immunoperoxidase study demonstrating the presence of numerous neuroendocrine products. Cancer 51:1483-1489, 1983

9. Arends JW, Wiggers T, Verstijnen K, Bosman FT. The occurrence and clinicopathological significance of serotonin immunoreactive cells in large bowel carcinoma. J Pathol 149:97-102, 1986

10. Hamada Y, Oishi A, Shoji T, Takada K, Yamamura M, Hioki K, Yamamoto M. Endocrine cells and prognosis in patients with colorectal carcinoma. Cancer 69:2641-2646, 1992

11. de Bruine AP, Wiggers T, Beek C, Volovics A, von Meyenfeldt M, Arends JW, Bosman FT. Endocrine cells in colorectal adenocarcinomas: Incidence, hormone profile, and prognostic relevance. Int $\mathrm{J}$ Cancer 54:765-771, 1993

12. Grabowski P, Schindler I, Anagnostopoulos I, Foss HD, Riecken EO, Mansmann U, Stein H, Berger G, Buhr HJ, Scherubl H. Neuroendocrine differentiation is a relevant prognostic factor in stage III-IV colorectal cancer. Eur J Gastroenterol Hepatol 13:405-411, 2001

13. Swatek J, Chibowski D. Endocrine cells in colorectal carcinomas. Immunohistochemical study. Pol J Pathol 51:127-136, 2000

14. Smith DM Jr, Haggitt RC. The prevalence and prognostic significance of argyrophil cells in colorectal carcinomas. Amj Surg Pathol 8:123-128, 1984

15. Foley EF, Gaffey MJ, Frierson HF Jr. The frequency and clinical significance of neuroendocrine cells within stage III adenocarcinomas of the colon. Arch Pathol Lab Med 122:912-914, 1998

16. Secco GB, Campora E, Fardelli R, Lapertosa G, De Lucchi F, Gianquinto D, Bonfante P. Chromogranin-A expression in neoplastic neuroendocrine cells and prognosis in colorectal cancer. Tumori 82:390-393, 1996 
17. Mori M, Mimori K, Kamakura T, Adachi Y, Ikeda Y, Sugimachi K. Chromogranin-positive cells in colorectal carcinoma and transitional mucosa. J Clin Pathol 48:754-758, 1995

18. Pagani A, Papotti M, Abbona GC, Bussolati G. Chromogranin gene expressions in colorectal adenocarcinomas. Mod Pathol 8:626-632, 1995

19. Ferrero S, Buffa R, Pruneri G, Siccardi AG, Pelagi M, Lee AK, Coggi G, Bosari S. The prevalence and chnical significance of chromogranin A and secretogranin II immunoreactivity in colorectal adenocarcinomas. Virchows Arch 426:587-592, 1995

20. Park JG, Choe GY, Helman LJ, Gazdar AF, Yang HK, Kim JP, Park SH, Kim YI. Chromogranin-A expression in gastric and colon cancer tissues. Int J Cancer 51:189-194, 1992

21. Indinnimeo M, Cicchini C, Memeo L, Stazi A, Provenza C, Ricci F, Mingazzini PL. Correlation between chromogranin-A expression and pathological variables in human colon carcinoma. Anticancer Res 22:395-398, 2002

22. Yao GY, Zhou JL, Lai MD, Chen XQ, Chen PH. Neuroendocrine markers in adenocarcinomas: An investigation of 356 cases. World J Gastroenterol 9:858-861, 2003

23. Hamilton K, Chiappori A, Olson S, Sawyers J, Johnson D, Washington K. Prevalence and prognostic significance of neuroendocrine cells in esophageal adenocarcinoma. Mod Pathol 13:475-481, 2000

24. Spechler SJ, Goyal RK. Barrett's esophagus. N Engl J Med 315:362-371, 1986

25. Shia J, Tickoo SK, Guillem JG, Qin J, Nissan A, Hoos A, Stojadinovic A, Ruo L, Wong WD, Paty PB, Weiser MR, Minsky BD, Klimstra DS. Increased endocrine cells in treated rectal adenocarcinomas: A possible reflection of endocrine differentiation in tumor cells induced by chemotherapy and radiotherapy. Am J Surg Pathol 26:863-872, 2002

26. Wijnhoven BP, Siersema PD, Hop WC, van Dekken H, Tilanus HW. Adenocarcinomas of the distal oesophagus and gastric cardia are one clinical entity. Rotterdam Oesophageal Tumour Study Group. Br J Surg 86:529-535, 1999

27. Ruol A, Parenti A, Zaninotto G, Merigliano S, Costantini M, Cagol M, Alfieri R, Bonavina L, Peracchia A, Ancona E. Intestinal metaplasia is the probable common precursor of adenocarcinoma in Barrett esophagus and adenocarcinoma of the gastric cardia. Cancer 88:2520-2528, 2000

28. Tezel E, Nagasaka T, Nomoto S, Sugimoto H, Nakao A. Neuroendocrine-like differentiation in patients with pancreatic carcinoma. Cancer 89:2230-2236, 2000

29. Schleusener JT, Tazelaar HD, Jung SH, Cha SS, Cera PJ, Myers JL, Creagan ET, Goldberg RM, Marschke RF Jr. Neuroendocrine differentiation is an independent prognostic factor in chemotherapy-treated nonsmall cell lung carcinoma. Cancer 77:1284-1291, 1996

30. Griffin M, Sweeney EC. The relationship of endocrine cells, dysplasia and carcinoembryonic antigen in Barrett's mucosa to adenocarcinoma of the oesophagus. Histopathology 1 1:53-62, 1987

31. Rindi G, Bishop AE, Daly MJ, Isaacs P, Lee FI, Polak JM. A mixed pattern of endocrine cells in metaplastic Barrett's oesophagus. Evidence that the epithelium derives from a pluripotential stem cell. Histochemistry 87:377-383, 1987

32. Buchan AM, Grant S, Freeman HJ. Regulatory peptides in Barrett's oesophagus. J Pathol 146:227-234, 1985

33. Jaskiewicz K, Louw J, Anichkov N. Barrett's oesophagus: Mucin composition, neuroendocrine cells, p53 protein, cellular proliferation and differentiation. Anticancer Res 14:1907-1912, 1994

34. Feurle GE, Helmstaedter V, Buehring A, Bettendorf U, Eckardt VF. Distinct immunohistochemical findings in columnar epithelium of esophageal inlet patch and of Barrett's esophagus. Dig Dis Sci 35:86-92, 1990

35. Kirkland SC. Clonal origin of columnar, mucous, and endocrine cell lineages in human colorectal epithelium. Cancer 61:1359-1363, 1988

36. de Bruine AP, Dinjens WN, Pijls MM, vd Linden EP, Rousch MJ, Moerkerk PT, de Goeij AF, Bosman FT. NCI-H7 16 cells as a model for endocrine differentiation in colorectal cancer. Virchows Arch B Cell Pathol Incl Mol Pathol 62:311-320, 1992

37. Sanduleanu S, De Bruine A, Stridsberg M, Jonkers D, Biemond I, Hameeteman W, Lundqvist G, Stockbrugger RW. Serum chromogranin A as a screening test for gastric enterochromaffin-like cell hyperplasia during acid-suppressive therapy. Eur J Clin Invest 31:802-811, 2001

38. Colombo B, Curnis F, Foglieni C, Monno A, Arrigoni G, Corti A. Chromogranin A expression in neoplastic cells affects tumor growth and morphogenesis in mouse models. Cancer Res 62:941-946, 2002

39. Haggitt RC, Tryzelaar J, Ellis FH, Colcher H. Adenocarcinoma complicating columnar epitheliumlined (Barrett's) esophagus. Am J Clin Pathol 70:1-5, 1978 